\begin{tabular}{|c|c|}
\hline & $\begin{array}{l}\text { International Journal of Trend in Scientific } \\
\text { Research and Development (IJTSRD) }\end{array}$ \\
\hline 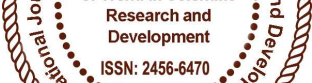 & International Open Access Journal \\
\hline 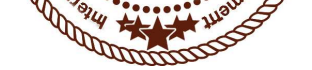 & ISSN No: 2456 - 6470 | www.ijtsrd.com | Volume - 2 | Issue - 2 \\
\hline
\end{tabular}

\title{
A Study of Child Abuse in India: Current Issues and Prevention
}

\author{
Dr. Geeta Yadav \\ Assistant Professor, \\ Indira Gandhi University \\ Meerpur, Rewari, Haryana, India
}

\author{
Nisha Yadav \\ Assistant Professor, \\ Indira Gandhi University \\ Meerpur, Rewari, Haryana, India
}

\author{
Pooja Yadav \\ Assistant Professor, \\ Indira Gandhi University \\ Meerpur, Rewari, Haryana, India
}

\section{ABSTRACT}

Child abuse is the physical or psychological maltreatment of a child, can be differentiated into four major categories, physical abuse, emotional abuse, neglect and worst of all; the sexual abuse. Child Sexual Abuse (CSA) is a kind of physical or mental violation of a child with sexual intent, usually by a person who is in a position of trust or power vis-à-vis the child. India is the second largest child population in the world, $42 \%$ of India's total population is below eighteen years. In a shocking revelation, a Government commissioned survey has found that more than $53 \%$ of Indian children are subjected to sexual abuse / assault. Majority of these cases were perpetrated by someone known to the child or in a position of trust and responsibility, Not surprisingly, most children did not report the abuse to anyone. There is not a single law aimed at safeguarding children and protecting them against sexual abuse \& assault, which is a serious lacuna against this background and is needed urgently. This paper will focus on child sexual abuse, impact and solution.

Keywords: abuse, child sexual abuse, law and effectiveness

\section{INTRODUCTION}

Child sexual abuse is a traumatic event in the life of a child. According to the WHO (1999), it results in actual or potential harm to a child's health, survival, development, or dignity in the context of a relationship of responsibility, trust, or power. Child abuse is defined as a non-accidental behaviour by parents, caregivers, or any other adults that is outside the norms of conduct and can cause physical or emotional harm to a child or a young person (Bromfield, 2005).

India houses $40 \%$ of children in its total population but is ranked as the sixth most unsafe country for children. In 2007, Ministry of Women and Child Welfare, supported by United Nations Children's Fund, save the children and Prays conducted a study to understand the magnitude of child abuse in India; they found that $53.22 \%$ children faced one or more forms of sexual abuse; among them, the number of boys abused was $52.94 \%$ and of girls was $47.06 \%$. Among the $69 \%$ of physically abused in 13 sample states, $54.68 \%$ were boys and $88.6 \%$ were physically abused by parents. Sixty-five percent of school going children reported facing corporal punishment; 50.2\% of children worked all 7 days in a week and they never reported abuse to anyone. Children on the street, children at work, and children in institutional care reported highest incidence of sexual assault.

Child sexual abuse is a punishable act as per the Protection of Children from Sexual Offenses Act the bill passed in the parliament in May 2012

Child sexual abuse is a dark reality that routinely inflicts our daily lives but in majority of cases unnoticed and unreported on account of the innocence of the victim, stigma attached to the act, insensitivity of the investigating and the law enforcement agencies 
etc. India is second most populous country in the world. Nearly $19 \%$ of the world's children live in India, which constitutes $42 \%$ of India's total population and around $50 \%$ of these children are in need of care and protection.

\section{Definition of child abuse}

The term 'Child Abuse' may have different connotations in different cultural milieu and socioeconomic situations. A universal definition of child abuse in the Indian context does not exist and has yet to be defined. According to WHO2:

Physical Abuse: Physical abuse is the inflicting of physical injury upon a child. This may include burning, hitting, punching, shaking, kicking, beating or otherwise harming a child. The parent or caretaker may not have intended to hurt the child. It may, however, be the result of over-discipline or physical punishment that is inappropriate to the child's age.

Sexual Abuse: Sexual abuse is inappropriate sexual behaviour with a child. It includes fondling a child's genitals, making the child fondle the adult's genitals, intercourse, incest, rape, sodomy, exhibitionism and sexual exploitation. To be considered 'child abuse', these acts have to be committed by a person responsible for the care of a child (for example a baby-sitter, a parent, or a day care provider), or related to the child. If a stranger commits these acts, it would be considered sexual assault and handled solely by the police and criminal courts.
Emotional Abuse: Emotional abuse is also known as verbal abuse, mental abuse, and psychological maltreatment. It includes acts or the failures to act by parents or caretakers that have caused or could cause, serious behavioural, cognitive, emotional, or mental trauma. This can include parents/caretakers using extreme and/or bizarre forms of punishment, such as confinement in a closet or dark room or being tied to a chair for long periods of time or threatening or terrorizing a child. Less severe acts, but no less damaging, are belittling or rejecting treatment, using derogatory terms to describe the child, habitual tendency to blame the child or make him/her a scapegoat.

Neglect: It is the failure to provide for the child's basic needs. Neglect can be physical, educational, or emotional. Physical neglect can include not providing adequate food or clothing, appropriate medical care, supervision, or proper weather protection (heat or cold). It may include abandonment. Educational

\section{OBJECTIVES}

The objectives of the study were:

To assess the magnitude and forms of child abuse in India.

To facilitate analysis of the existing legal framework to deal with the problem of child abuse in the country.

To recommend strategies and programme interventions for preventing and addressing issues of child abuse. 


\section{Child abuse in India}

\section{RAPE OF CHILDREN \\ Neighbours the biggest predators \\ Relationship Cases under POCSO Percentage Act Sec 4 \& 6 (rape)

\begin{tabular}{lrr} 
Neighbour & 3,149 & 35.78 \\
\hline Employer/co-worker & 2,227 & 25.30 \\
\hline Grandfather/father/brother etc. & 138 & 1.56 \\
\hline Other close family member & 210 & 2.38 \\
\hline Relativesother than closefamily & 581 & 6.60 \\
\hline Other known person & 2,036 & 23.13
\end{tabular} \\ Total number of rape cases \\ Only 251 cases under Child \\ 8,800 \\ Labour Act \\ 449 \\ children rescued}

\section{MOST CASES OF ABUSE BY FAMILY AND RELATIVES}

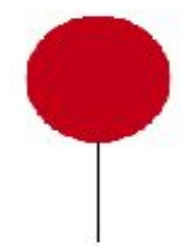

169

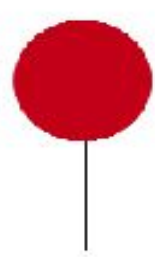

154

Uttar

Praclesh

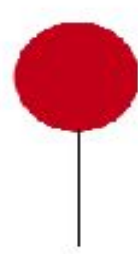

125

Tamil

Nadu

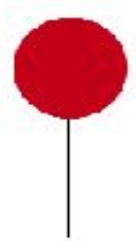

106

Gujarat

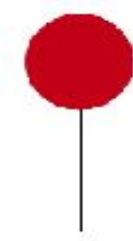

96

Madhya Prackesh

\section{Current position of child abuse in India}

\section{Physical Abuse-}

1. Two out of every three children were physically abused.
8. Most children did not report the matter to anyone.

2. Out of $69 \%$ children physically abused in $13-9.50 .2 \%$ children worked seven days a week. sample states, $54.68 \%$ were boys.

3. 3. Over $50 \%$ children in all the 13 sample states were being subjected to one or the other form of physical abuse.

4. Out of those children physically abused in family situations, $88.6 \%$ were physically abused by parents.

5. $65 \%$ of school going children reported facing corporal punishment i.e. two out of three children were victims of corporal punishment.

6. $62 \%$ of the corporal punishment was in government and municipal school.

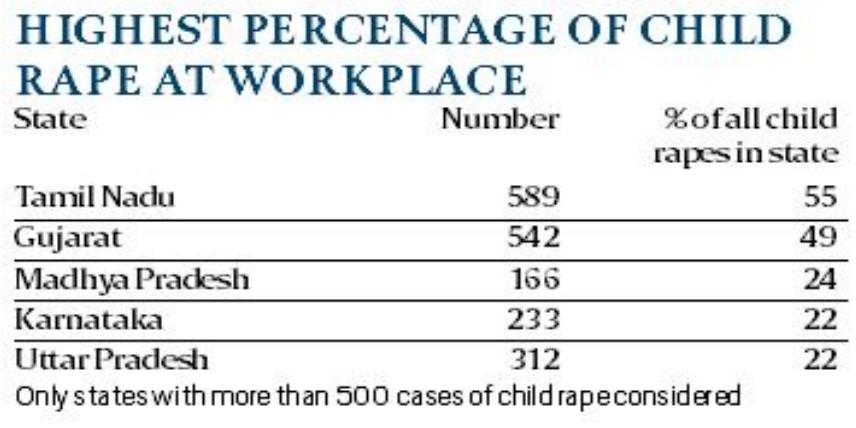

\begin{tabular}{|c|c|c|}
\hline \multicolumn{3}{|c|}{$\begin{array}{l}\text { WORST RATE AND CRIME } \\
\text { NUMBERS UNDER POCSO }\end{array}$} \\
\hline & $\begin{array}{r}\text { Per } 1 \text { lakh } \\
\text { child population }\end{array}$ & Cases \\
\hline Madhya Pradesh & 11.9 & 1,480 \\
\hline Chhattisgarh & 11.6 & 1,164 \\
\hline Karnataka & 7.6 & 1,560 \\
\hline Odisha & 6.8 & 1,416 \\
\hline Assam & 6.1 & 731 \\
\hline Maharashtra & 5.6 & 1,687 \\
\hline
\end{tabular}

\section{CHILD TRAFF ICKING DOMINATES} ALL HUMAN TRAFFICKING

\begin{tabular}{lrrr} 
State & $\begin{array}{r}\text { All human } \\
\text { trafficking } \\
\text { cases }\end{array}$ & $\begin{array}{r}\text { Child } \\
\text { trafficking } \\
\text { cases }\end{array}$ & Percentage \\
WestBengal & 1,255 & 1,119 & 89 \\
\hline Assam & 1,494 & 1,317 & 88 \\
\hline Bihar & 381 & 332 & 87 \\
\hline Haryana & 275 & 200 & 73 \\
\hline All India & 6,877 & 3,490 & 51
\end{tabular}
Delhi have almost consistently reported higher rates of abuse in all forms as compared to other states.

\section{Sexual Abuse-}

1. $53.22 \%$ children reported having faced one or more forms of sexual abuse.

2. Andhra Pradesh, Assam, Bihar and Delhi reported the highest percentage of sexual abuse among both boys and girls.

3. $21.90 \%$ child respondents reported facing severe forms of sexual abuse and $50.76 \%$ other forms of sexual abuse.

4. Out of the child respondents, 5.69\% reported being sexually assaulted.
7. "The State of Andhra Pradesh, Assam, Bihar and 
5. Children in Assam, Andhra Pradesh, Bihar and Delhi reported the highest incidence of sexual assault.

6. Children on street, children at work and children in institutional care reported the highest incidence of sexual assault.

7. $50 \%$ abuses are persons known to the child or in a position of trust and responsibility.

8. Most children did not report the matter to anyone.

\section{Emotional Abuse and Girl Child Neglect}

1. Every second child reported facing emotional abuse.

2. Equal percentage of both girls and boys reported facing emotional abuse.

3. In $83 \%$ of the cases parents were the abusers.

4. $48.4 \%$ of girls wished they were boys.

\section{HOW TO PREVENT CHILD ABUSE}

1. Understand that "child abuse" means any kind of harm done to a child and does not just mean sexual abuse.

2. Teach your children that there is a difference between "good" and "bad" touches. Explain what these are.

3. Explain that no one has the right to hurt your child or touch him or her in private areas or touch in any way that makes him or her feel uncomfortable.

4. Tell your children that the words they need to remember are No, Go, Yell, Tell. If anyone touches them in a way they don't like or tries to get them to go with a stranger or person they don't feel comfortable with they should always say "No!" and ...

5. Go away from the person or situation as quickly as possible.

6. Use their danger voice to yell. A danger voice is a very loud, low-pitched yell, that gets attention immediately. It is not a high-pitched screech. It should never be used in any other situation.

7. Tell a parent, teacher or caregiver immediately about what happened.
8. Help your children understand that they need to be wary not just of the traditional idea of "strangers" but of anyone who makes them feel uncomfortable, even if it is someone they know like the next-door neighbor.

9. Talk to your children about situations they must avoid, like taking any food or medicine from a person who is not a parent, teacher, caregiver or close friend. Help them understand how to identify a police officer. Take them to the local police station and let them see what a uniform looks like and what a badge looks like.

10. Show your children how to make a collect call to home and how to call Child Protection Services.

11. Learn what the signs of abuse are so that you will notice if something is going on with your child. Look for bruises, burns, bloody or missing underwear, difficulty with bowel movement or urination, problems with walking or sitting, behavior problems, inappropriate sexual behavior, sore genitals or anything that just makes you feel there is something amiss.

12. Get help from the police, social services department or through a child abuse hotline if you suspect there is a problem.

13. Life skills training for children and young adults to equip children, adolescents, and young adults with interpersonal skills and knowledge that are valuable in adulthood, especially in the parenting role; and second, to provide children with skills to help them protect themselves from abuse.

14. Effective 'Child Protection Policy' be placed in an organizational context to ensure a well-trained workforce, to develop responses using a range of disciplines, to provide alternative care placements for children, to ensure access to health resources, to provide resource for families and to report the suspected abuse at the earliest in an appropriate manner. Promote Child Abuse preventive programmes in schools, child-care-centers and communities.

\section{CONCLUSION}

To make this world safer for children, we need to protect our sons and daughters equally. Patriarchy is not protecting our boys more than our girls in childhood. The very low rates of reporting and help seeking among victims of sexually abused 
boys in India could be due to the hegemony of patriarchy. This social construct is usually being applied to understand the subordination of girls and women, the fact that it is oppressing all children who are perfect victims irrespective of their gender is being ignored in male children who are expected to be superior due to their biology and also because of this myth of superiority, there are unethical expectations for them to overcome the harmful effects of sexual abuse of childhood without treatment

\section{REFERENCE}

1) Bromfield, L. M. (2005). Chronic child maltreatment in an Australian Statutory child protection sample (Unpublished doctoral dissertation). Deakin University, Geelong.

2) Behere PB, Sathyanarayana Rao TS, Mulmule AN. Sexual abuse in women with special reference to children: Barriers, boundaries and beyond. Indian J Psychiatry. 2013;55:3169. [PMC free article] [PubMed]

3) Ministry of Women and Child Development, Government of India. Study on Child Abuse: India 2007. New Delhi: Ministry of Women and Child Development, Government of India; 2007. [Last accessed on 2012 Jan 28]. Available from: http://www.wcd.nic.in/childabuse.pdf.

4) Ministry of Law and Justice, Government of India. Protection of Children from Sexual Offences Act, 2012.New Delhi: Ministry of Law and Justice, Government of India; 2012. [Last accessed on 2012 Nov 28]. Available from: http://www.wcd.nic.in/childact/childprotecti on

5) Subramaniyan VK, Mital A, Rao C, Chandra G. Barriers and challenges in seeking psychiatric intervention in a general hospital, by the collaborative child response unit, (a multidisciplinary team approach to handling child abuse) A qualitative analysis. Indian J Psychol Med. 2017;39:12-20. [PMC free article] [PubMed] 